\title{
Arterial endothelin-1 level in pulmonary emphysema and interstitial lung disease. Relation with pulmonary hypertension during exercise
}

\author{
T. Yamakami, O. Taguchi, E.C. Gabazza, M. Yoshida, T. Kobayashi, H. Kobayashi, \\ H. Yasui, H. Ibata, Y. Adachi
}

\begin{abstract}
Arterial endothelin-1 level in pulmonary emphysema and interstitial lung disease. Relation with pulmonary hypertension during exercise. T. Yamakami, O. Taguchi, E.C. Gabazza, M. Yoshida, T. Kobayashi, H. Kobayashi, H. Yasui, H. Ibata, Y Adachi. (CERS Journals Ltd 1997.

ABSTRACT: This study was undertaken to assess the arterial plasma levels of endothelin-1 (ET-1) and their relationship with pulmonary haemodynamic and gas exchange variables during exercise in patients with emphysema and interstitial lung disease (ILD).

Incremental cycle ergometry was performed in all patients up to maximal capacity. At rest, arterial ET-1 levels were higher in emphysema $\left(1.86 \pm 0.35 \mathrm{pg} \cdot \mathrm{mL}^{-1}\right.$; $\mathrm{p}<0.02)$ and ILD $\left(1.75 \pm 0.25 \mathrm{pg} \cdot \mathrm{mL}^{-1} ; \mathrm{p}<\mathbf{0 . 0 3}\right)$ patients than in controls $(1.35 \pm 0.18$ $\left.\mathrm{pg} \cdot \mathrm{mL}^{-1}\right)$. Emphysema $\left(2.08 \pm 0.26\right.$ versus $\left.1.70 \pm 0.40 \mathrm{pg} \cdot \mathrm{mL}^{-1}\right)$ and ILD $(1.98 \pm 0.21$ versus $\left.1.67 \pm 0.02 \mathrm{pg} \cdot \mathrm{mL}^{-1}\right)$ patients with pulmonary hypertension $(\mathrm{PH})$ presented significantly $(p<0.05)$ higher arterial ET-1 levels than those without. At rest, arterial ET-1 levels were significantly correlated with mean pulmonary arterial pressure $\left(\bar{P}_{\text {pa }}\right)$ in both ILD $(\mathrm{r}=0.8, \mathrm{p}=0.01)$ and emphysema $(\mathrm{r}=0.5, \mathrm{p}=0.03)$ patients. During exercise, the arterial ET-1 levels were significantly correlated with arterial oxygen $\left(P \mathrm{a}_{1}, \mathrm{O}_{2}\right)(\mathrm{r}=-0.6, \mathrm{p}=0.04)$, alveolar-arterial oxygen difference $(\mathrm{r}=0.8, \mathrm{p}=0.01)$, and $\bar{P}_{\mathrm{pa}}$ $(\mathrm{r}=0.6, \mathrm{p}=0.04)$ in ILD patients, but not in those with emphysema.

In brief, the results of this study suggest that arterial endothelin-1 is markedly increased in interstitial lung disease and emphysema patients, and that, it is related to the exercise-induced exacerbation of pulmonary hypertension in patients with interstitial lung disease, but not in those with emphysema.
\end{abstract}

Eur Respir J 1997; 10: 2055-2060.

Third Dept of Internal Medicine, Mie University School of Medicine, Mie prefecture, Tsu-city, Japan.

Correspondence: T. Yamakami

514 Edobashi 2-chome

174 banchi

Tsu-city

Mie prefecture

Japan

Keywords: Emphysema endothelin-1

exercise

interstitial lung disease

pulmonary hypertension

Received: November 261996

Accepted after revision June 251997
Pulmonary artery hypertension is the major cardiovascular complication of emphysema and advanced interstitial lung disease (ILD) [1]. Pulmonary hypertension $(\mathrm{PH})$ is important, not only because it is associated with right ventricular hypertrophy (or cor pulmonale) but also because it adversely affects prognosis in these patients [2]. The mechanisms responsible for $\mathrm{PH}$ include thrombotic obstruction of pulmonary blood vessels, reduced distensibility of the pulmonary vascular bed, pulmonary vascular obstruction produced by medial hypertrophy or intimal proliferation, and pulmonary vasoconstriction elicited by acute or chronic alveolar hypoxia [3, 4]. Of these, hypoxic vasoconstriction has been considered one of the major factors involved in the pathogenesis of sustained $\mathrm{PH}$ or in the development of acute exacerbation of $\mathrm{PH}$ in patients with emphysema or advanced ILD [5]. However, the precise mechanism by which hypoxia induces pulmonary vasoconstriction and the structural changes that ensue from chronic hypoxia have not been fully elucidated. Endothelin-1 (ET1), a vasoconstricting peptide originally isolated from cultured human endothelial cells, may play a relevant role in the pathogenesis of $\mathrm{PH}$ during hypoxia [6-8]. This assumption is supported by previous findings that showed that the endothelium-dependent vasoconstric- tion depends on an increased release of ET-1 from vessels in rats and that hypoxia stimulates ET-1 secretion from endothelial cells $[9,10]$. In addition, another study demonstrated that acute pulmonary alveolar hypoxia increases lung and plasma ET-1 levels in conscious experimental animals and that this peptide increase is parallel to the severity of arterial hypoxaemia [11]. An important factor that worsens hypoxaemia, pulmonary alveolar hypoxia, and PH is exercise performance [12]. We hypothesized that circulating levels of ET-1 might play an important role in the exacerbation of $\mathrm{PH}$ during exercise in patients with chronic hypoxia. To test this hypothesis, in the present study, we evaluated the changes in the arterial levels of ET-1 and their relation with pulmonary haemodynamic and gas exchange variables during exercise in patients with ILD and pulmonary emphysema.

\section{Subjects and methods}

This study comprised 11 patients with ILD (seven males, four females, mean age $56.7 \pm 2.5 \mathrm{yrs}$ ) and 17 with pulmonary emphysema ( 17 males, mean age $67.1 \pm 1.4$ yrs) admitted to our institution between May 1993 and 
August 1994 because of dyspnoea on exertion. The diagnosis of emphysema was performed according to the criteria of the American Thoracic Society, and the diagnosis of ILD on the basis of histological findings of biopsy specimens [13]. Pulmonary function tests were performed using a volume-type spirometer (Chestac-55V, Chest MI Co., Tokyo, Japan). The results of the spirometric study are detailed in table 1 . All patients with emphysema had air flow limitation with forced expiratory volume in one second (FEV1) of $<60 \%$ predicted. Patients with ILD presented restrictive spirometric findings with a vital capacity of $<75 \%$. Right heart catheterization was performed using a Swan-Ganz catheter (131H-7F; Baxter Healthcare Co., Irvin, CA, USA) inserted into a basilic vein of patients in supine position under local anaesthesia and placed in the pulmonary artery under electrocardiographic and fluoroscopic monitoring. The exercise testing method was the incremental cycle ergometry [14]. Each patient exercised in a supine position against progressive workloads applied every 2 min up to (symptom-limited) maximum exercise capacity. Measurement of haemodynamic parameters and sampling of arterial blood from a radial artery line for determination of blood gas and ET-1 values were performed simultaneously at rest, at maximal exercise capacity and after 10 and $60 \mathrm{~min}$ of the recovery period. Electrocardiogram, systemic arterial pressure and pulmonary artery pressure were continuously monitored. The arterial partial pressure of oxygen $\left(\mathrm{Pa}_{\mathrm{a}} \mathrm{O}_{2}\right)$ and carbon dioxide $\left(\mathrm{Pa}_{\mathrm{a}}, \mathrm{CO}_{2}\right)$ were measured using a blood gas analyser (ABL510; radiometer Co., Copenhagen, Denmark). CO was measured by the thermodilution method as previously described [14]. In the present study, patients of each group of disease were assigned into two groups: patients with $\mathrm{PH}$ (at rest mean pulmonary artery pressure $\bar{P}$ pa $>20 \mathrm{mmHg}$; at rest pulmonary vascular resistance $(\mathrm{PVR})>300$ dyn $\cdot \mathrm{s} \cdot \mathrm{cm}^{-5}$ ) and without $\mathrm{PH}$ (at rest $\bar{P}_{\mathrm{pa}}: \leq 20 \mathrm{mmHg}$; at rest PVR $\leq 300 \mathrm{dyn} \cdot \mathrm{s} \cdot \mathrm{cm}^{-5}$ ), based on values reported previously [15].

Arterial blood for measuring ET-1 levels was collected in chilled vacutainers containing disodium dihydrogen ethylenediamine tetra-acetate dihydrate, and then centrifuged at $3,000 \times \mathrm{g}$ for $20 \mathrm{~min}$, to obtain plasma. The plasma was aliquoted and frozen at $-80^{\circ} \mathrm{C}$ until analysis. Arterial ET-1 levels were measure by radioimmunoassay as described previously [16]. Briefly, the samples were extracted using C18 cartridges (SepPak, Waters, Mississauga, Ontario, Canada) activated by methTable 1. - pulmonary function test in each group of patients

\begin{tabular}{llcc}
\hline & & Emphysema patients & ILD patients \\
\hline $\mathrm{VC}$ & $\mathrm{mL}$ & $2526 \pm 181$ & $2001 \pm 201$ \\
& $\%$ pred & $78 \pm 5$ & $64 \pm 5$ \\
$\mathrm{FEV} 1$ & $\mathrm{~mL}$ & $1127 \pm 153$ & $1614 \pm 205$ \\
& $\%$ pred & $47 \pm 3$ & $81 \pm 4$ \\
$T \mathrm{~L}, \mathrm{CO} / V \mathrm{~A}$ & $\%$ pred & $28 \pm 3$ & $67 \pm 7$ \\
$\mathrm{~Pa}_{2} \mathrm{O}_{2}$ & $\mathrm{mmHg}$ & $77 \pm 3$ & $84 \pm 4$ \\
$\mathrm{~Pa}, \mathrm{CO}_{2}$ & $\mathrm{mmHg}$ & $41 \pm 1$ & $39 \pm 1$ \\
\hline
\end{tabular}

Values are presented as mean \pm SD. ILD: interstitial lung disease; VC: vital capacity; $\%$ pred: percentage of predicted value; $\mathrm{FEV} 1$ : forced expiratory volume in one second; $T \mathrm{~L}, \mathrm{CO} / V \mathrm{~A}$ : transfer factor of the lungs for carbon monoxide/alveolar volume; $\mathrm{Pa}, \mathrm{O}_{2}$ : arterial oxygen tension; $\mathrm{Pa}_{\mathrm{a}} \mathrm{CO}_{2}$ : arterial carbon dioxide tension $1 \mathrm{mmHg}=0.133 \mathrm{kPa}$. anol, and $8 \mathrm{M}$ urea and water and then eluted by $100 \%$ methanol. Samples and standards (synthetic endothelin-1; Peptide Institute, Osaka, Japan) were reconstituted in assay buffer and incubated with rabbit antiendothelin-1 antiserum (Peninsula Laboratories, Belmont, CA, USA) at $4^{\circ} \mathrm{C}$ for $24 \mathrm{~h}$. This was followed by the addition of 125I-labelled ET-1 (Amersham International Amersham, UK) and a second $24 \mathrm{~h}$ incubation. Bound and free radioactivity was separated by the second antibody method, and the gamma emission from the precipitate of antibody-ET-1 complexes was counted using a gamma counter. The intra- and interassay coefficients of variation were 10 and $13 \%$, respectively. Arterial ET-1 levels measured in five healthy male volunteers at rest, during maximum exercise and during the recovery period, were available for comparison. The exercise protocol for the healthy controls was the same as that described above for ILD and emphysema patients, but pulmonary artery catheterization was not performed. Informed consent was obtained from each subject enrolled in this investigation. The study was approved by the Ethics Committee of our University and carried out following the principles of the Helsinki Declaration.

\section{Statistical analysis}

All data are expressed as the mean \pm SD unless otherwise specified. The difference among the means of various variables was assessed by the Friedman one-way analysis of variance. The difference between the means of two variables was calculated by the Mann-Whitney U-test. The strength of correlation between variables was analysed by the Pearson product-moment correlation or by the Spearman correlation according to the Gaussian distribution of the data. A p-value less than 0.05 was considered statistically significant. Statistical analyses were carried out using the StatView 4.5 package software for the Macintosh (Abacus Concepts, Berkeley, CA, USA).

\section{Results}

At rest, increased levels of arterial ET-1 were observed in patients with emphysema $\left(1.86 \pm 0.35 \mathrm{pg} \cdot \mathrm{mL}^{-1}\right.$; $\mathrm{p}<0.02)$ and ILD $\left(1.75 \pm 0.25 \mathrm{pg} \cdot \mathrm{mL}^{-1} ; \mathrm{p}<0.03\right)$ as compared to normal controls $\left(1.35 \pm 0.18 \mathrm{pg} \cdot \mathrm{mL}^{-1}\right.$; fig. 1$)$. Emphysema patients with $\mathrm{PH}\left(2.08 \pm 0.26 \mathrm{pg} \cdot \mathrm{mL}^{-1}\right)$ presented significantly $(\mathrm{p}<0.04)$ higher arterial concentration of ET-1 as compared to those $\left(1.78 \pm 0.40 \mathrm{pg} \cdot \mathrm{mL}^{-1}\right)$ without this vascular complication. Similarly, arterial ET-1 levels were also significantly $(\mathrm{p}<0.05)$ higher in the group of ILD patients with $\mathrm{PH}\left(1.98 \pm 0.21 \mathrm{pg} \cdot \mathrm{mL}^{-1}\right)$ than in those $\left(1.67 \pm 0.02 \mathrm{pg} \cdot \mathrm{mL}^{-1}\right)$ without this complication (fig. 1). The relationship of arterial ET-1 levels and haemodynamic and blood gas parameters, at rest and during exercise, is shown in table 2 . In patients with ILD, the at rest values of arterial ET-1 correlated significantly with the resting values of the $\bar{P}_{\text {pa }}$ (fig. $2 \mathrm{a}$ ), $P a, \mathrm{O}_{2}$ (fig. 2a) and alveolar-arterial oxygen difference $\left(D \mathrm{~A}-\mathrm{a}, \mathrm{O}_{2}\right)$, but weakly with the PVR at rest. There was no significant statistical correlation between the arterial ET-1 concentrations at rest and those of $\mathrm{Pa}_{\mathrm{a}} \mathrm{CO}_{2}$, cardiac frequency and the blood pressures in ILD patients. In patients with emphysema, the resting arterial ET-1 


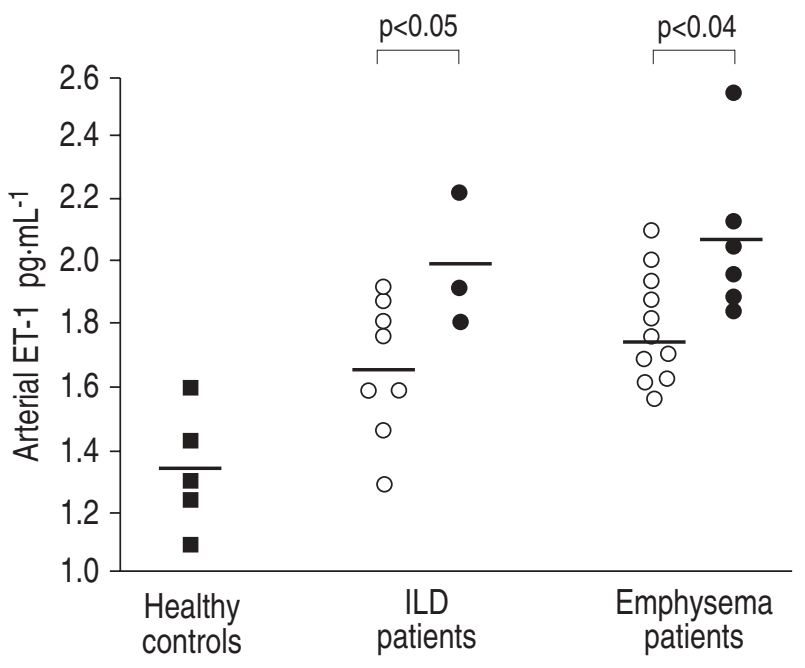

Fig. 1. - Arterial endothelin-1 (ET-1) levels in healthy controls and emphysema and interstitial lung disease (ILD) patients with or without pulmonary hypertension (PH). Emphysema and ILD patients with PH $(\bullet)$ presented significantly higher arterial ET-1 levels as compared to those without PH (O).

a)
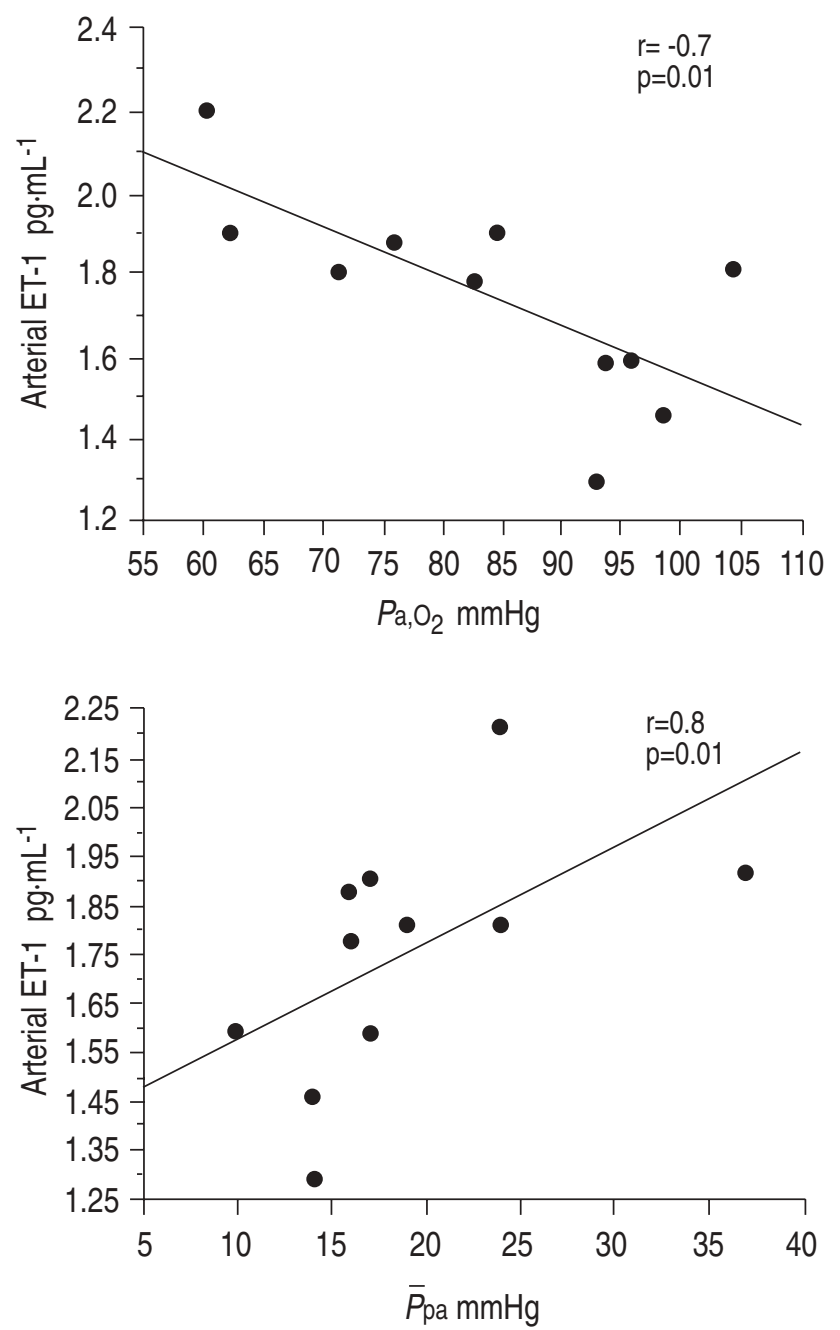

Table 2. - Correlation coefficients between arterial endothelin-1 levels and haemodynamic and blood gas variables at rest and during exercise

\begin{tabular}{|c|c|c|c|c|c|c|c|c|}
\hline & \multicolumn{4}{|c|}{ At rest } & \multicolumn{4}{|c|}{ At maximum exercise } \\
\hline & \multicolumn{2}{|c|}{ Emphysema } & \multicolumn{2}{|c|}{ ILD } & \multicolumn{2}{|c|}{ Emphysema } & \multicolumn{2}{|c|}{ ILD } \\
\hline & $\mathrm{r}$ & $\mathrm{p}$ & $\mathrm{r}$ & $\mathrm{p}$ & $\mathrm{r}$ & $\mathrm{p}$ & $\mathrm{r}$ & $\mathrm{p}$ \\
\hline $\mathrm{Pa}, \mathrm{O}_{2}$ & -0.4 & 0.10 & -0.7 & 0.01 & -0.2 & 0.50 & -0.6 & 0.04 \\
\hline $\mathrm{Pa}_{\mathrm{a}, \mathrm{CO}_{2}}$ & +0.3 & 0.10 & -0.4 & 0.7 & +0.1 & 0.60 & -0.6 & 0.07 \\
\hline $\mathrm{DA}-\mathrm{a}, \mathrm{O}_{2}$ & $0_{2}-0.1$ & 0.80 & +0.8 & 0.01 & +0.1 & 0.50 & +0.8 & 0.01 \\
\hline$P_{\mathrm{v}}, \mathrm{O}_{2}$ & -0.0 & 0.90 & -0.0 & 0.9 & +0.4 & 0.09 & -0.6 & 0.06 \\
\hline $\bar{P}_{\mathrm{pa}}$ & +0.5 & 0.03 & +0.8 & 0.01 & -0.1 & 0.50 & +0.6 & 0.04 \\
\hline$P$ paw & -0.4 & 0.10 & -0.3 & 0.3 & -0.4 & 0.10 & -0.3 & 0.40 \\
\hline PVR & +0.6 & 0.04 & +0.6 & 0.07 & 0.0 & 0.90 & +0.4 & 0.30 \\
\hline $\bar{Q}^{\prime}$ & +0.2 & 0.40 & +0.6 & 0.05 & 0.0 & 0.90 & +0.0 & 0.80 \\
\hline$P_{\text {sys }}$ & +0.1 & 0.20 & -0.0 & 0.7 & -0.1 & 0.70 & +0.5 & 0.10 \\
\hline
\end{tabular}

$D \mathrm{~A}-\mathrm{a}, \mathrm{O}_{2}$ : alveolar-arterial oxygen difference; $\mathrm{P}_{\mathrm{v}}, \mathrm{O}_{2}$ : mixed venous oxygen tension; $\bar{P}$ pa: mean pulmonary artery pressure; $P$ paw: pulmonary artery wedge pressure; PVR: pulmonary vasculatory resistance; $Q^{\prime}$ : cardiac output; $P$ sys: systemic blood pressure. For further definitions see legend to table 1.

b)
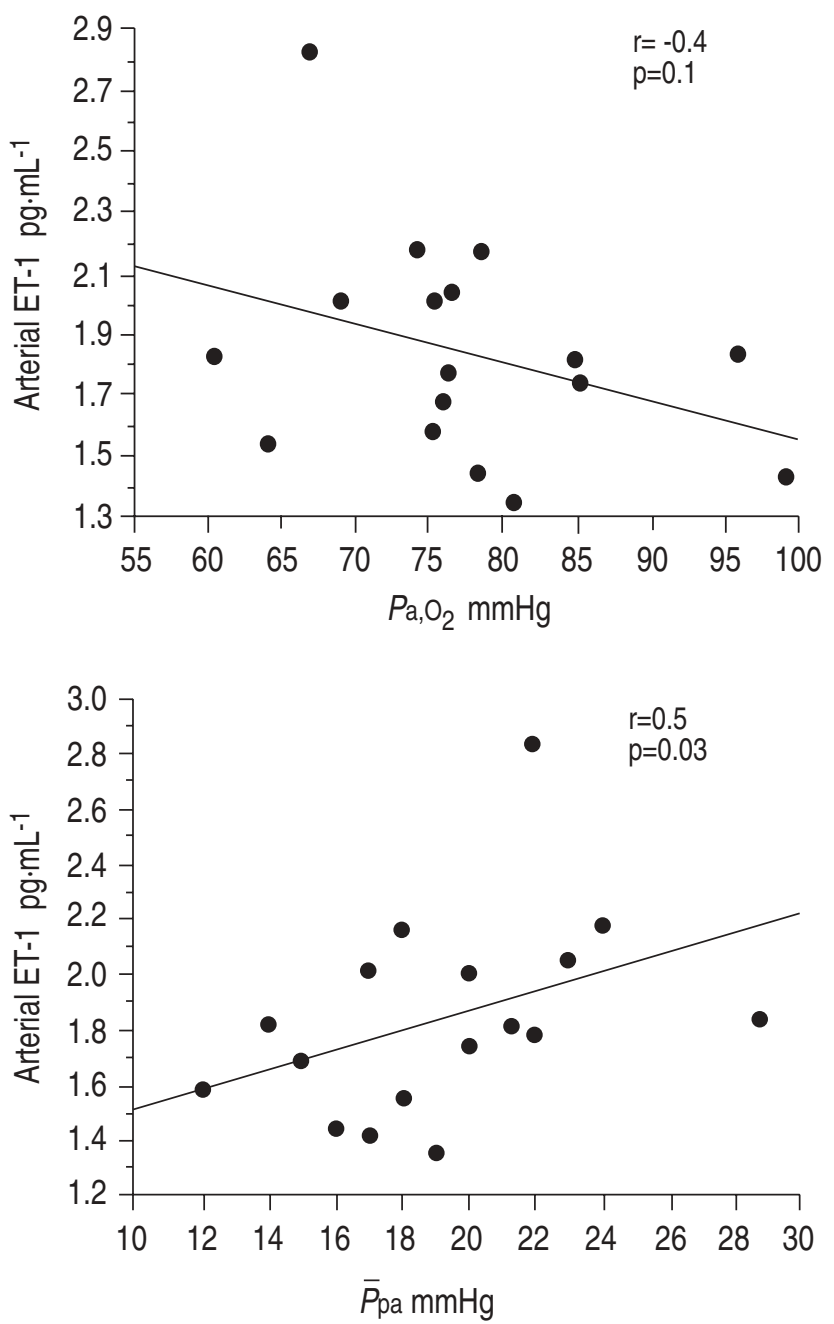

Fig. 2. - Arterial endothelin-1 (ET-1) levels, resting $P_{\mathrm{a}, \mathrm{O}_{2}}$ and mean pulmonary artery pressure $\left(\bar{P}_{\text {pa }}\right)$ in patients with: a) interstitial lung disease (ILD); and b) emphysema. ET-1 levels were significantly correlated with both arterial oxygen tension $\left(P_{\mathrm{a}}, \mathrm{O}_{2}\right)$ and $\bar{P}_{\mathrm{pa}}$ in ILD. In emphysema, ET-1 levels were significantly correlated with $\vec{P}_{\mathrm{pa}}$, but not with $\mathrm{Pa}_{\mathrm{a}} \mathrm{O}_{2} .1 \mathrm{mmHg}=0.133 \mathrm{kPa}$. 
a)
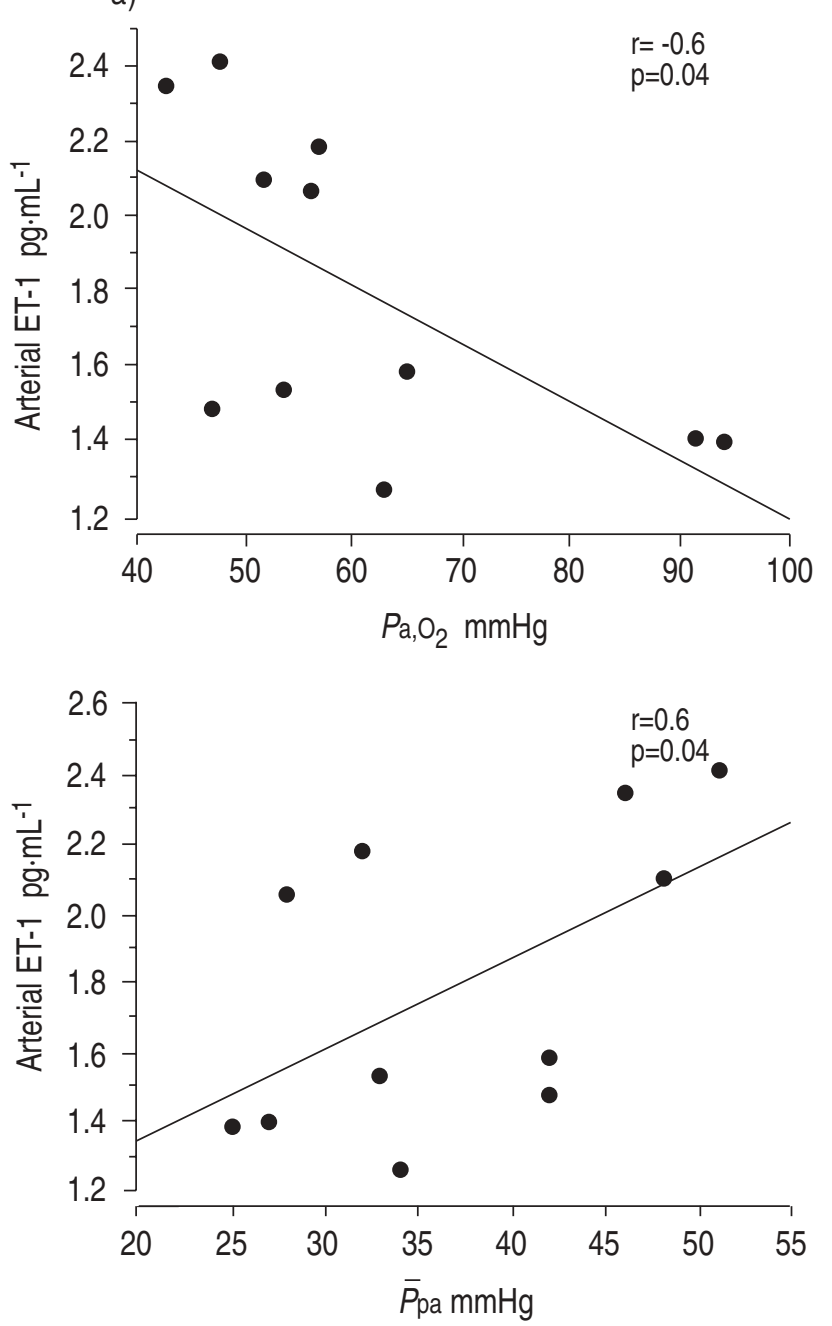

b)
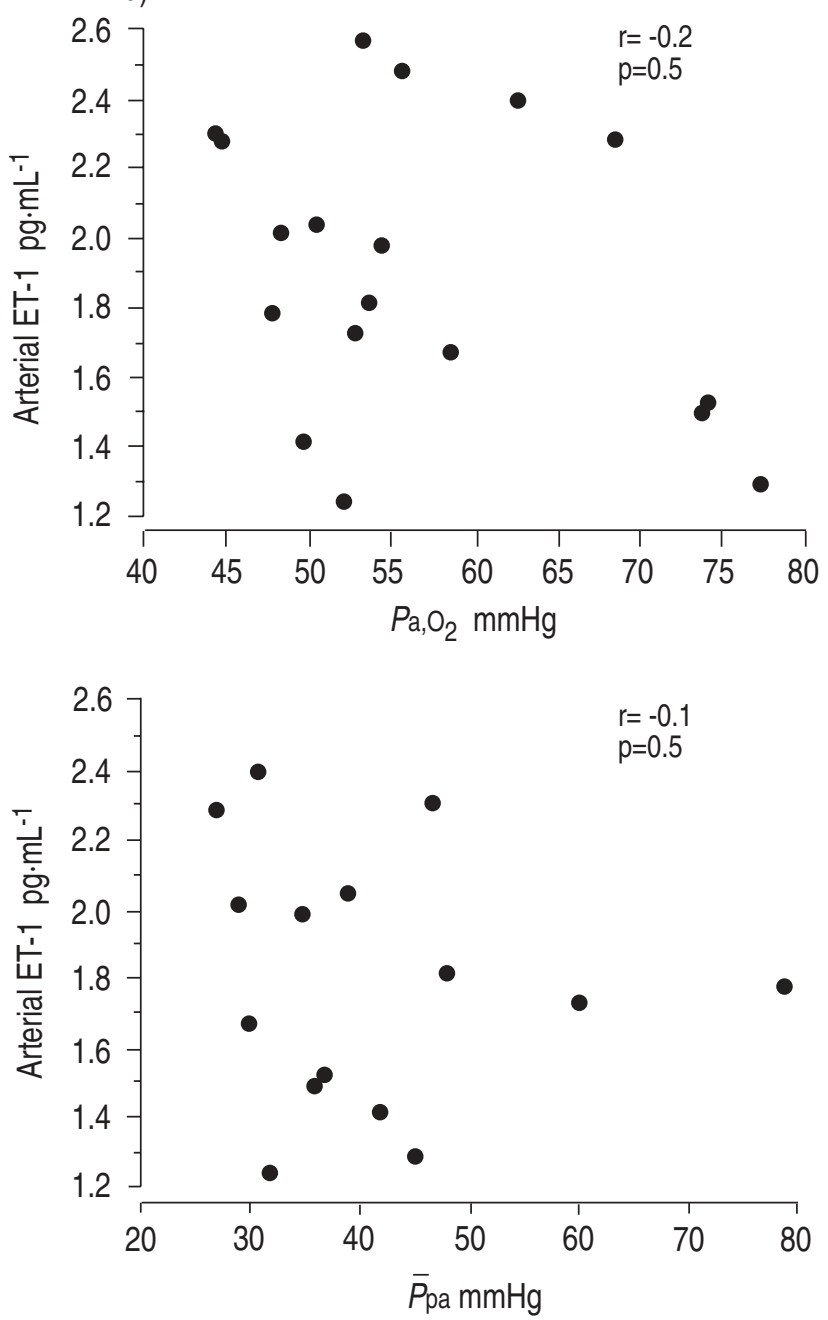

Fig. 3. - Arterial endothelin-1 (ET-1) levels during maximal exercise, arterial oxygen tension $\left(P\right.$ a, $\left.\mathrm{O}_{2}\right)$ and mean pulmonary artery pressure $\left(\bar{P}_{\text {pa }}\right)$ in patients with: a) interstitial lung disease (ILD); and b) emphysema. During maximum exercise, the arterial ET-1 levels were significantly correlated with $\mathrm{Pa}_{\mathrm{a}} \mathrm{O}_{2}$ and $\bar{P}_{\mathrm{pa}}$ in patients with ILD, but not in those with emphysema. $1 \mathrm{mmHg}=0.133 \mathrm{kPa}$.

levels were significantly correlated with $\bar{P}_{\text {pa }}$ (fig. 2 b), but they were not correlated with the resting $P \mathrm{a}, \mathrm{O}_{2}$ (fig. $2 \mathrm{~b})$ or with other circulatory or blood gas parameters.

During maximum exercise, $\bar{P}$ pa $(18.90 \pm 7.30 \mathrm{mmHg})$ significantly $(\mathrm{p}<0.05)$ increased in all ILD or emphy-

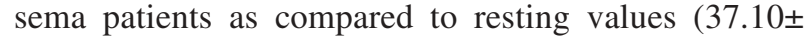
$9.10 \mathrm{mmHg}$ ). The arterial ET-1 levels during maximum exercise capacity significantly increased in ILD patients with resting $\mathrm{PH}\left(\mathrm{n}=3 ; 1.98 \pm 0.20 \mathrm{pg} \cdot \mathrm{mL}^{-1} ; \mathrm{p}<0.05\right)$ as compared to resting values, but not in those without this vascular complication $\left(\mathrm{n}=8 ; 1.67 \pm 0.20 \mathrm{pg} \cdot \mathrm{mL}^{-1}\right)$. The arterial ET-1 levels did not change significantly at maximal exercise capacity in emphysema patients with $(n=6)$ or without $(n=11)$ pulmonary hypertension (data not shown). At maximal exercise capacity, the arterial ET-1 levels were significantly correlated with $\mathrm{Pa}, \mathrm{O}_{2}$ (fig. 3a), $\mathrm{DA}-\mathrm{a}, \mathrm{O}_{2}$ and $\bar{P}_{\text {pa }}$ (fig. $3 \mathrm{a}$ ) in patients with ILD, but not in those with emphysema (fig. $3 b$ ).

The arterial concentration of ET-1 measured during the recovery period at 10 and $60 \mathrm{~min}$ after exercise tended to decrease gradually in both ILD (10 min: $1.56 \pm 0.36$ $\left.\mathrm{pg} \cdot \mathrm{mL}^{-1} ; 60 \mathrm{~min}: 1.37 \pm 0.28 \mathrm{pg} \cdot \mathrm{mL}^{-1}\right)$ and emphysema (10 min: $1.79 \pm 0.39 \mathrm{pg} \cdot \mathrm{mL}^{-1} ; 60 \mathrm{~min}: 1.66 \pm 0.53 \mathrm{pg} \cdot \mathrm{mL}^{-1}$ ) patients. The arterial ET-1 levels did not change significantly in healthy subjects at maximal exercise capacity or during the recovery period as compared to values measured at rest.

At rest and during maximal exercise, the $\mathrm{Pa}, \mathrm{O}_{2}$ values were significantly correlated with $\bar{P}_{\text {pa }}$ (at rest: r= $-0.6, \mathrm{p}<0.05$; during exercise: $\mathrm{r}=-0.7, \mathrm{p}<0.02$ ) but weakly with PVR (at rest: $\mathrm{r}=-0.6, \mathrm{p}=0.08$; during exercise: $\mathrm{r}=-0.8, \mathrm{p}=0.06)$ in ILD patients. The $\mathrm{Pa}, \mathrm{O}_{2}$ values also tended to correlate with $\bar{P}_{\mathrm{pa}}$ and PVR at rest and during exercise in patients with emphysema, but not at statistically significant levels (data not shown). The workloads (in watts), arterial blood pressures, $D$ A-a, $\mathrm{O}_{2}, \mathrm{~Pa}_{\mathrm{a}} \mathrm{O}_{2}$, $P$ a, $\mathrm{CO}_{2}, \mathrm{PVR}$, cardiac frequency and $\bar{P}$ pa during maximal exercise were not significantly different between patients with ILD and emphysema.

\section{Discussion}

Increased pulmonary and peripheral blood levels of ET-1 have been described in, and postulated to contribute to, the pathophysiology of several lung diseases such as primary $\mathrm{PH}$, bronchial asthma, acute lung 
injury and cryptogenic fibrosing alveolitis [8, 17-21]. In accord with this, in the current study, the plasma arterial levels of ET-1 were also found to be significantly elevated in patients with various interstitial lung disorders and in those with emphysema. The source of ET1 can be the vascular or nonvascular tissues of the lung and the peripheral circulation [22]. In the lung, ET-1 can be produced by endothelial, tracheal, bronchial and alveolar epithelial cells, and by tissue macrophages [23, 24]. Once released from these cells, the peptide can act locally to elicit sustained pulmonary artery vasoconstriction, bronchoconstriction, activation of alveolar macrophages leading to the release of eicosanoids and increased superoxide production $[25,26]$. ET-1 can also exert proliferative activity on fibroblasts, smooth muscle and endothelial cells [24, 27, 28]. The biological activity of ET-1 on the pulmonary vasculature is believed to play an essential role in the pathogenesis of secondary PH including that associated with cryptogenic fibrosing alveolitis [18, 21]. This assumption is supported by the results of the present study, which disclosed a significant increase in the circulating levels of ET-1 in ILD or emphysema patients with PH as compared to those observed in cases without this vascular complication. Furthermore, a previous study performed using an experimental animal model showed that the progression of $\mathrm{PH}$ is attenuated by the systemic administration of a selective ET-1 type A receptor antagonist (BQ-123) [29].

Pulmonary hypertension, a frequent vascular complication of ILD or pulmonary emphysema, commonly worsens during exercise. Enhanced pulmonary vasoconstriction and/or right ventricular failure have been shown to be amongst causative factors of acute exacerbation of PH during exercise [4, 5]. Acute alveolar hypoxia, which causes pulmonary vasoconstriction in vitro and in vivo, is believed to play an important role in the increase of pulmonary artery pressure during exercise [30]. The precise mechanism of this response is not known. Alveolar hypoxia may potentially act by inducing increased in situ expression of vasoconstricting substances in the lung. In this connection, increased levels of catecholamines, vasopressin, angiotensin or ET-1 have been described during exercise [31-33]. However, their physiopathological significance in the exerciseinduced pulmonary haemodynamic and gas exchange abnormalities has not as yet been established. In the present study, to gain some insights into the mechanism of the exercise-induced $\mathrm{PH}$, we compared the relationship of peripheral arterial ET-1 levels and the increase of PH during exercise between ILD and emphysema patients. As expected, PH worsened and was correlated with arterial hypoxaemia in patients with or without $\mathrm{PH}$. Arterial levels of ET-1 were significantly correlated with $\bar{P}$ pa in ILD patients exercising at maximal work capacity. In patients with emphysema, however, ET-1 arterial concentration was not correlated with the increase in $\bar{P}_{\mathrm{pa}}$ values during exercise. Overall, although correlation does not prove a cause-and-effect relationship, these findings suggest that ET-1 might play a role in the increase of pulmonary artery pressure during exercise in ILD patients, but not in those with emphysema. Interestingly, $\bar{P}$ pa was also inversely correlated with $P$ a, $\mathrm{O}_{2}$ during exercise in ILD, but not in emphysema patients.
Points that need further clarification are the explanation for the elevated levels of ET-1 without any change in $P$ pa observed in some of our patients, particularly in those with pulmonary emphysema, as well as the mechanism by which the arterial ET-1 levels failed to increase during exercise in patients with emphysema. Previous studies performed in rats suggested that the receptors for ET-1 are mainly distributed in the lungs and, to lesser extent, in the kidneys and liver [34, 35]. It could be suggested that a decrease in the number of intrapulmonary receptors for ET-1 may be responsible for the lack of hypertensive response in some of our patients with emphysema with increased arterial ET-1 levels. Conversely, increased consumption of the peptide during exercise might be the mechanism by which ET-1 did not increase in patients with emphysema during exercise performance. In this connection, the removal of the peptide, particularly by the lungs, was previously reported to be high (60\%), and alveolar hypoxia may further enhance the pulmonary uptake of the ET-1 by activating its intrapulmonary receptors [36-38]. In addition, the need for a higher degree of hypoxaemia to trigger the secretion of ET-1 in emphysema patients than in those with ILD may also explain the lack of correlation of ET-1 with PH during exercise in the former group of patients. The increased uptake of ET-1 by its peripheral receptors may also explain the gradual decrease in the ET-1 circulating levels observed in our patients during the recovery period. In agreement with this, previous studies performed in experimental animal models also showed that circulating ET-1 levels decrease significantly in the postexercise (recovery) period [39].

In summary, this study showed for the first time: 1) the presence of increased circulating levels of endothelin-1 in patients with emphysema, particularly in those with pulmonary hypertension; 2) the association of increased arterial endothelin-1 levels with the exacerbation of pulmonary hypertension during exercise in interstitial lung disease patients; and 3) high levels of arterial endothelin-1 that remained unchanged during exercise in patients with emphysema.

\section{References}

1. Fishman AP. Pulmonary Hypertension and Core Pulmonale. 2nd Edn. Tokyo, MacGraw-Hill Book Company, 1990, pp. 999-1048.

2. Renzetti AD Jr, McClement JH, Litt BD. The Veterans administration cooperative study of pulmonary function. III, Mortality in relation to respiratory function in chronic obstructive pulmonary disease. Am J Med 1966; 41: $115-119$.

3. Kennedy JI, Fulmer JD. Pulmonary hypertension in the interstitial lung diseases. Chest 1985; 87: 558-560.

4. Macnee W. Pathophysiology of cor pulmonale in chronic obstructive pulmonary disease. Am J Respir Crit Care Med 1994; 150: 833-852.

5. Bye PTP, Anderson SD, Woolcock AJ, et al. Bicycle endurance performance of patients with interstitial lung disease breathing air and oxygen. Am Rev Respir Dis 1982; 126: 1005-1012.

6. Yanagisawa M, Kurihara H, Kmura S, et al. A novel potent vasoconstrictor peptide produced by vascular endothelial cells. Nature 1988; 332: 411-415.

7. Yoshibayashi M, Nishioka K, Nakao K. Plasma 
endothelin concentrations in patients with pulmonary hypertension associated with congenital heart defects: evidence for increased production of endothelin in pulmonary circulation. Circulation 1991 ; 84: 2280-2285.

8. Giaid A, Yanagisawa M, Langleben D, et al. Expression of endothelin-1 in the lungs of patients with pulmonary hypertension. N Engl J Med 1993; 328: 1732-1739.

9. Rakugi H, Tabuchi Y, Nakamaru M, et al. Evidence for endothelin-1 release from resistance vessels of rats in response to hypoxia. Biochem Biophys Res Commun 1990; 169: 973-977.

10. Kourembanas S, Marsden PA, McQuillan LP, Faller DV. Hypoxia induces endothelin gene expression and secretion in cultured human endothelium. J Clin Invest 1991; 88: 1054-1057.

11. Shirakami G, Nakao K, Saito Y, et al. Acute pulmonary alveolar hypoxia increases lung and plasma endothelin-1 levels in conscious rats. Life Sci 1991; 48: 969-976.

12. Ries AL. The role of exercise testing in pulmonary diagnosis. Clin Chest Med 1987; 8: 81-89.

13. American Thoracic Society. Standards for the diagnosis and care of patients with chronic obstructive pulmonary disease. Am J Respir Crit Care Med 1995; 152: S77-S120.

14. Wasserman K, Hansen JE, Sue DY, Whipp BJ, Casaburi R. Principles of Exercise Testing and Interpretation. 2nd Edn. Tokyo, Japan, Lea \& Febiger, 1994.

15. Murray JF. The Normal Lung. The Basis of Diagnosis and Treatment of Pulmonary Disease. 2nd Edn. Philadelphia, W.B. Saunders, 1986, pp. 23-59.

16. Okada M, Yamashita K, Okada M, Okada K. Contribution of endothelin-1 to warm ischemia/reperfusion injury of the rat lung. Am J Respir Crit Care Med 1995; 152: 2105-2110.

17. Redington AE, Springall DR, Ghatei MA, et al. Endothelin in bronchoalveolar lavage fluid and its relation to airflow obstruction in asthma. Am J Respir Crit Care Med 1995; 151: 1034-1039.

18. Stelzner TJ, O'Brien RF, Yanagisawa M, et al. Increased lung endothelin-1 production in rats with idiopathic pulmonary hypertension. Am J Physiol 1992; 262: L614-L620.

19. Steward DJ, Levy RD, Cernacek P, Langleben D. Increased plasma endothelin-1 in pulmonary hypertension: marker or mediator of disease? Ann Intern Med 1991; 114: 464-469.

20. Langleben D, Demarchie M, Laporta D, Spanier AH, Schlesinger RD, Stewart DJ. Endothelin-1 in acute lung injury and the adult respiratory distress syndrome. Am Rev Respir Dis 1993; 148: 1646-1650.

21. Giaid A, Michel RP, Stewart DJ, Shepard M, Corrin B, Hamid Q. Expression of endothelin-1 in lungs of patients with cryptogenic fibrosing alveolitis. Lancet 1993; 341: 1550-1554.

22. Hay DWP, Henry PJ, Goldie RG. Endothelin and the respiratory system. Trends Pharmacol Sci 1993; 14: 29-32.

23. Luscher TF. Endothelin. J Cardiovasc Pharmacol 1992; 18: S15-S22.

24. Markewitz BA, Kohan DE, Michael JR. Endothelin-1 synthesis, receptors, and signal transduction in alveolar epithelium: evidence for an autocrine role. Am J Physiol 1995; 268: L192-L200.

25. Vierhapper H, Wagner O, Nowotny P, Waldhausl W. Effects of endothelin-1 in man. Circulation 1990; 81: $1415-1418$.

26. Lippton HL, Hauth TA, Summer WR, Hyman AL. Endothelin produces pulmonary vasoconstriction and systemic vasodilation. J Appl Physiol 1989; 66: 1088-1112.

27. Komuro I, Kurihara T, Takaku F, Yazaki Y. Endothelin stimulates c-fos and c-myc expression and proliferation of vascular smooth muscle cells. FEBS Lett 1988; 238 : 249-252.

28. Kahaleh MB. Endothelin, an endothelial-dependent vasoconstrictor in scleroderma. Enhance production and profibrotic action. Arth Rheum 1991; 34: 978-983.

29. Miyauchi T, Yurikane R, Sakaki S, et al. Contribution of endogenous endothelin- 1 to the progression of cardiopulmonary alterations in rats with monocrotalininduced pulmonary hypertension. Circ Res 1993; 73: 887-897.

30. Fishman AP. Hypoxia on the pulmonary circulation: how and where it acts. Circ Res 1976; 38: 221-231.

31. Stebbins CL, Symons JD, McKirnan MD, Hwang FF. Factors associated with vasopressin release in exercising swine. Am J Physiol 1994; 266: R118-R124.

32. Kashimura O, Sakai A, Yanagidaira Y. Effect of exercise-training on hypoxia and angiotensin II-induced pulmonary vasoconstriction. Acta Physiol Scand 1995; 155: 291-295.

33. Ahlborg G, Weitzberg E, Lundberg J. Metabolic and vascular effects of circulating endothelin-1 during moderately heavy prolonged exercise. J Appl Physiol 1995; 78: 2294-2300.

34. Shiba R, Yanagisawa M, Miyauchi T, et al. Elimination of intravenously injected endothelin-1 from the circulation of the rat. J Cardiovasc Pharmacol 1989; 13: S98-S101.

35. Miyazaki H, Kondoh M, Masuda Y, Watanabe H, Murakarni K. Endothelin receptors and receptor subtypes. In: Rubanyi GM, ed. Endothelin. New York, Clinical Physiology Series, American Physiological Society, 1992; pp. 58-71.

36. De Nucci G, Thomas R, D'Orleans-Juste P, Antunes E, Walder C. Pressor effects of circulating endothelin are limited by its removal in the pulmonary circulation and by the release of prostacyclin and endothelium-derived relaxing factor. Proc Natl Acad Sci USA 1988; 85: 9797-9800.

37. Koseki C, Imai M, Hirata Y, Yanagisawa M, Masaki T. Autoradiographic distribution in rat tissues of binding sites for endothelin: a neuropeptide? Am J Physiol 1989; 256: R858-R866.

38. Li H, Elton T, Chen Y, Oparil S. Increased endothelin receptor gene expression in hypoxic rat lung. Am J Physiol 1994; 266: 553-560.

39. Allevard A, Gauquelin G, Gharib C. Endothelin and atrial natriuretic peptide after exercise performed until exhaustion in the rat. Life Sci 1991; 49: 1803-1808. 